\title{
Policy evaluation of village fund through an agro-tourism village for sustainable local development
}

\section{Evaluasi kebijakan dana desa melalui desa wisata agro guna menciptakan pembangunan local berkelanjutan}

\author{
Christina Tityanda Putri ${ }^{1 *}$, Bintoro Wardiyanto ${ }^{2}, \&$ Falih Suaedi ${ }^{2}$ \\ ${ }^{1}$ Master Program of Public Policy, Faculty of Social and Political Science, Universitas Airlangga \\ ${ }^{2}$ Department of Public Administration, Faculty of Social and Political Science, Universitas Airlangga \\ Address: ${ }^{1,2}$ Jalan Dharmawangsa Dalam, Airlangga, Surabaya, East Java 60286 \\ E-mail: christina.tityanda@gmail.com
}

\begin{abstract}
Village fund as a tool for policy strategy that Indonesia constructed from the periphery. The purpose of the village fund is to improve the welfare and quality of life of village people, manifested by encouraging the development of independent and sustainable villages with social, economic, and environmental resilience. The amount of budget allocation is designed to build Indonesia from a small scale and drive the revival and passion for creativity and innovation in all elements of the village. Pujon Kidul Village is a village in Malang District that serves as a reference 'building village' in the development of an agro-tourism village. Using a qualitative approach to a descriptive method, this research was collected from the village head and the government of Pujon Kidul, as well as NGOs and purposive societies, totaling approximately 15 informants. The findings show the development of tourism village Pujon Kidul has successfully brought change for the local community, especially in the development of human resources using natural resources. Both synergize and complement each other without elements of exploitation and are managed by the village-owned enterprises or Badan Usaha Milik Desa (BUMDesa), which has the authority to include the village in the government's policy of building from the suburbs (village) to create sustainable development-based localities. Village level policy is a new era of the form of an independent government and encourages the realization of community participation to accelerate the progress of the village and leave the old village mindset behind.
\end{abstract}

Keywords: community empowerment; sustainable local development; village fund

\begin{abstract}
Abstrak
Dana desa sebagai alat untuk strategi kebijakan Indonesia dibangun dari pinggiran atau pedesaan. Kewajiban penyaluran dana desa ditujukan untuk meningkatkan kesejahteraan dan kualitas hidup masyarakat desa. Perwujudannya yakni dengan mendorong pembangunan desa-desa mandiri dan berkelanjutan dengan memiliki ketahanan sosial, ekonomi, dan lingkungan. Besarnya alokasi anggaran untuk membangun Indonesia dari skala kecil, yakni desa menumbuhkan kebangkitan dan gairah kreatifitas dan inovasi di segenap elemen desa. Desa Pujon Kidul adalah salah satu desa di Kabupaten Malang menjadi rujukan 'desa membangun' dalam pengembangan desa wisata agro. Sesuai dengan peraturan menteri desa dan pembangunan daerah tertinggal dan transmigrasi (PDTT), bahwa dana desa digunakan untuk prioritas pembangunan dan pemberdayaan masyarakat. Dengan menggunakan metode deskriptif, hasil penelitian menunjukkan berkembangnya Desa Wisata Pujon Kidul yang berhasil membawa perubahan bagi masyarakat setempat, terutama dalam pembangunan Sumber Daya Manusia (SDM) yang bermodal Sumber Daya Alam (SDA). Kreatifitas Desa Pujon Kidul gayung bersambut dengan adanya dana desa sehingga melahirkan berbagai unit dalam Badan Usaha Milik Desa (BUMDesa) sebagai buah kepemimpinan sang kepala desa dan sportivitas masyarakat desa. Keduanya bersinergi saling melengkapi tanpa unsur eksploitasi dikelola oleh BUMDesa yang diberikan wewenang agar desa menghidupkan kebijakan Pemerintah Indonesia membangun dari daerah pinggiran (desa) untuk menciptakan pembangunan yang berkelanjutan berbasis lokalitas. Kebijakan level desa merupakan era baru wujud pemerintahan yang mandiri dan mendorong perwujudan partisipasi masyarakat untuk percepatan kemajuan desa serta meninggalkan pola pikir lama desa yang tertinggal.
\end{abstract}

Kata kunci: pemberdayaan masyarakat; pembangunan lokal berkelanjutan; dana desa 


\section{Introduction}

Since Law Number 6, the Year 2014 on villages was implemented, it has meant that the old paradigm of 'building villages' into 'developing villages' has shifted the village concept's models. The government believes that starting the development spirit from rural areas can overcome social and economic inequality and accelerate poverty alleviation. This law concerns and implies that the village fund or dana desa is a fund sourced from the state revenue and expenditure budget designated for the village and transferred through the regional district budget. Research on village fund indicates it is intended to finance government administration, development implementation, community development, and community empowerment. The independence of an area is a reflection of the level of community participation in the development of that area. Communities in an area with a high level of participation can be said to reflect the area's high independence. Balan \& Burghelea (2015) also give a perspective that area independence is built from tourism development and its transformation so it can be impacted to have social, economic, and cultural implications.

One of the development policy priorities is focused on regional development to reduce disparities between regions. Efforts to reduce the gap between villages and cities are carried out by accelerating the development of independent villages and building local economic linkages between villages and cities through rural area development. One of the regencies in East Java Province located at the southern end of the province and is the second-largest regency after Surabaya as the Capital of the Province, is the subdistrict of Pujon where one of the villages has succeeded in developing economic potential in the form of nature and its natural resources as a driver of progress, through the utilization of village fund. Starting from a long-hidden community desire to see the natural potential and creativity of its citizens, but limited by budget funds, the village fund became a booster for village progress. Pujon Kidul Village, located in the Pujon Subdistrict through the village-owned enterprises or Badan Usaha Milik Desa (BUMDesa), drives its economy by exploring the potential of agro-tourism. Village tourism was developed from society's demand to reform the village become a new local destination as a place for vacations and also environmental conservation (Vitasurya \& Pudianti 2016).

The village is a legal community unit with territorial boundaries that are authorized to regulate and manage the interests of the local community, based on local origins and customs that are recognized and respected within the Government of the Unitary State of the Republic of Indonesia. The government of Indonesia designed a policy to build Indonesia, starting from a village as a state in miniature. The village is a government level at the community level that is limited by geographical areas and organizes government with a single dimension. Suryani \& Irfan (2016) described that villages having original ideas become an eye-catching tourist attraction. Villages in Indonesia are also inseparable from their origin, customs, and traditions. The village is also synonymous with areas that retain their natural qualities so that it has the uniqueness of the area through its original topographical location. In the context of public policy implementation, the village is the lowest level as a development destination for the periphery.

\section{Research Method}

In this research, a qualitative-descriptive approach was used by the researcher to find primary and secondary data. This method was a fit with this research because it can describe the policy of village funds in developing villages as the objective and then as the subject of development. The data were collected by field study, literature, norms, laws, and documents. The research location was Pujon Kidul Village, Malang, East Java. This research uses an in-depth interview with 15 key informants: 1) the head of the village of Pujon Kidul (Mr. Udi Hartoko), 2) Government Civil Servants (Secretary: Mr. Sudirman, Treasurer: Mr. Anas Taufiq, Village Consultative or Badan Permusyawaratan Desa $(B P D)$ \& Village Community Empowerment Institute or Lembaga Pemberdayaan Masyarakat Desa (LPMD): Mr. Subandi), and 3) other civil societies handling essential roles in using village fund to develop an Agro-Tourism Village (Mr. Udi Safii, Mr. Yogi, Mr. Irul and other authorized stakeholders). 


\section{Results and Discussion}

According to Anderson (1979), public policy can be defined as a deliberately relatively stable action designed by an actor or some actors to solve a problem or matters of mutual concern, while Dunn (2000) states that public policy is an intricate dependency pattern of interdependent collective choices, including decisions to act, made by government agencies or offices. Meanwhile, according to Dye (2013), public policy is what the government chooses to do. This public policy regulates behavior, organizes bureaucracy, distributes benefits and collects taxes, frequently at the same time. That is politicians situated in authoritative decision-making positions ultimately 'make' public policy. However, they do so most often by following the advice provided to them by civil servants and others whom they trust or rely upon to consolidate policy alternatives into more or less coherent designs and provide them with an expert opinion on the merits and demerits of the proposals put before them (Howlett 2011). Progress evaluation is not only challenging but vital, and organizations must be able to assess and demonstrate the value and outcome of their activities. Community indicators are presented, as well as a discussion of the quality of life and happiness considerations for communities (Phillips \& Pittman 2014).

According to some experts, public policy can be divided into three main processes: first, the policy formulation, which is where policy is planned or formulated, and goes through the study process on its feasibility. Second, policy implementation is where the policy that has been formulated is implemented according to the goal. The third is evaluation of the policy where evaluated or in impact in terms of outputs and outcomes. In this research, the researcher uses the policy evaluation cycle to indicate the output of the policy. In this context, policy evaluation is about describing how village fund is used well by Pujon Kidul Village in exploring their potential natural resources and becomes a process to empower societies to develop and have a more space to build up their capacity, all stages of the policy process and affect both the agenda-setting and policy formulation processes as well as being the subject of decision-making, policy implementation, and evaluation (Howlett 2019). The agro-tourism village was a concept created by the leader of the village, Mr. Udi Hartoko, to catch up with societies and engage with (and by) them to have a sustainable, better life. As Republic of Indonesia Law Number 6 of 2014 mandates:

"Village is a village and a customary village or what is referred to by another name, hereinafter referred to as Village, is a legal community unit that has the authority to manage and manage government affairs, the interests of the local community based on community initiatives, rights of origin, and / or rights traditionally recognized and respected in the government system of the Unitary Republic of Indonesia."

The political nature of judgments about policy success and failure also implies that such assessments will rarely be unanimous. It is, in part, because political evaluations depend in part on the imputation of notions of intentionality to government actors made by policy evaluators - so that the results of policymaking can be assessed against expectations (Howlett 2007). Dunn (2000) provides an overview of the evaluation model by applying public policy evaluation criteria (Table 1.)

The Ministry of Villages and Development of Disadvantaged Areas and Transmigration or Pembangunan Daerah Tertinggal dan Transmigrasi (PDTT) mandates that the village fund has priorities of use. Among the consequences of the implementation of Village Law, the central government allocated substantial funds for village development coming from the state budget, which is transferred to regency governments to be subsequently allocated for village development (Hartoyo et al.2018). The village should analyze some priorities of primary needs. According to the Government Regulation Number 222015 regarding the Amendment to Government Regulation Number 60 the year 2014 concerning village funds sourced from the country's income and expenditure budget, it explained that the decision and regulation of the Ministry of the Villages and PDTT must synergize with the regulation of the Minister of Home Affairs and the Minister of Finance in the determination of the priority of the use of village fund. Annually, through the Law of Village Minister, the priority of using village funds illustrated in Figure 1. 
Table 1.

Model evaluation by Dunn

\begin{tabular}{|c|c|c|}
\hline Criterion type & Questions & Illustration \\
\hline Effectiveness & Has the desired outcome been achieved? & Service Unit \\
\hline Efficiency & $\begin{array}{l}\text { How much effort is needed to achieve the } \\
\text { desired outcome? }\end{array}$ & $\begin{array}{l}\text { Cost unit, net benefit, cost-benefit } \\
\text { ratio }\end{array}$ \\
\hline Adequacy & $\begin{array}{l}\text { How far did the desired results solve the } \\
\text { problem? }\end{array}$ & Fixed costs, fixed effectiveness \\
\hline Alignment & $\begin{array}{l}\text { Are the benefits' costs evenly distributed } \\
\text { to different groups? }\end{array}$ & $\begin{array}{l}\text { Parito criteria, Kaldor-Hicks } \\
\text { criteria, Rawls criteria }\end{array}$ \\
\hline Responsiveness & $\begin{array}{l}\text { Do public policy results satisfy the needs, } \\
\text { preferences, or values of a particular } \\
\text { group? }\end{array}$ & Consistency with citizen surveys \\
\hline Accuracy & $\begin{array}{l}\text { Is the desired result (purpose) really } \\
\text { useful or worth it? }\end{array}$ & $\begin{array}{l}\text { Public programs must be evenly } \\
\text { and efficiently implemented. }\end{array}$ \\
\hline
\end{tabular}

Source: Dunn (2003:610)

The Pujon Kidul Village located in the subdistrict of Pujon, which includes regions with a plateau that has characteristics of hills and mountains, the more precise location is around $1.200 \mathrm{~m}$ above sea level. Further, its location is a potential ecology to develop a new local place to pull tourists magnetism. Because plateau has a low temperature where is the agro field can be grown productively. Nowadays, in order to develop tourism in the global era, an understanding of the resilience of the ecology's social system is essential (Setiawan et al. 2017).

However, policy evaluation is not an exclusive preserve of the government. It may also involve members of the public, who often will have an ultimate say on a government's policy record when they vote at elections or decide whether or not to co-operate with government expectations. Thus the sites of policy judgments are broader than often suggested, as many accounts tend to concentrate overwhelmingly on evaluations of success or failure made by bureaucrats and a small number of 'outside' actors, such as private consultants and think-tanks (Bovens et al. in Howlett 2007, Brandstrom \& Kuipers 2003). The source of the community economic strength of Pujon Kidul Village is a village business institution managed by the community and the village government to strengthen the economy of the village for the realization of the welfare of the village community. The dominant economic and social transformations in the contemporary period created and developed tourism, which, in turn, stimulated the development of other branches of the national economy through the subject of its activity, such as industry and agriculture, construction, transport, and trade (Balan \& Burghelea 2015). This business institution is a source of strength that encourages the creation of economic productivity for the village based on the potential of the village. The village owns all or part of the capital through direct capital inclusion derived from the wealth of the village. The villageowned enterprises (BUMDesa) were formed on the will of the village community, which was decided through the village deliberation or musyawarah desa (musdes). The village deliberation gave birth to various decisions ranging from the naming of the village-owned enterprises, the establishment of managers, and pennant business units.

Pujon Kidul village-owned enterprises, named Sumber Sejahtera, were formed in 2015 when Udi Hartoko served as the head of the Village of Pujon Kidul in the first period. Starting from Village Law mandate Number 6 the Year 2014 general provisions, the village-owned enterprise is a business entity that is all or mostly capital owned by the village through direct inclusion derived from the village's wealth and which are segregated to manage assets, service and other businesses for the maximum welfare of the village community. One of the strategic points of the village deliberation result was the formation of a village-owned enterprise, which authorizes the village so that it is more autonomous to take care of its own business to form an independent village. The competence of the village apparatus is necessary so that the management of village funds for the development of various aspects can be accomplished using intelligence, knowledge, and skills, and behaviors to promote 
optimal village development (Anto \& Amir 2017). The existence of the village-owned enterprise aims to jointly explore potential village potential in the village in order to increase the wheels of the economy of rural communities and also to help the national economic program. Apart from being a social and commercial institution, the village-owned enterprise is also a manifestation of the productive economic management of villages conducted in a coherent, transparent, and accountable manner. Through these mandates, government elements in Pujon Kidul agreed that they should have an organization to build something and decided to create the village-owned enterprise, namely Sumber Sejahtera. The village-owned enterprise had the vision to embody the village business entity to build a more empowered and competitive economy for the village community. The villageowned enterprise strives to be an economic institution capable of competitiveness in free-market competition and contributes to the development of the community-based economy. Development of village tourism or tourist village is also considered to have the ability to minimize the potential urbanization of society from rural to urban areas because it can create economic activity in rural areas based on tourism activities (tourism economy) (Hamzah \& Irfan 2018).

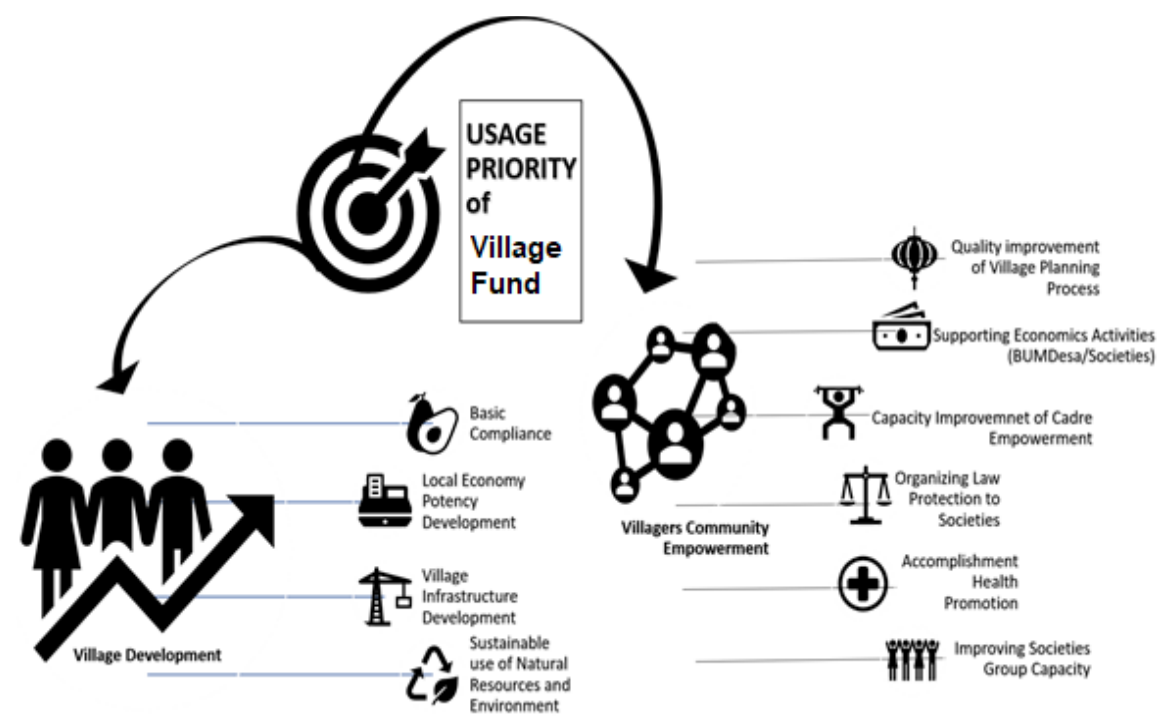

Figure 1.

Usage priorities of village funds (writer illustration made)

The existence of the village-owned enterprise is expected to be the backbone of the village community economy and can provide welfare for the people of Pujon Kidul Village. The mission of Sumber Sejahtera advancing aid or Bantuan Uang Muka (BUM): 1) raising the village economic value with potential village goods, 2) management of village potential according to community needs 3 ) assisting community financial services, and 4) increasing the village's first revenue or Pendapatan Asli Desa $(P A D)$. Local authorities have an essential role in regulating and managing the direction and policy development in the area on the Island of Lombok. There appears sufficient government apparatus to synergize with tourism stakeholders to bring and advance the tourist areas; its sustainability can be seen from the local tourism industry (Suryani \& Irfan 2016). The mission is a concrete step expected by the village in Pujon to accelerate the economic development of rural communities. The villageowned enterprise can spearhead the activities and economic development of village communities. The existence of a village-owned enterprise should be based on community needs so that it has an excellent benefit for the village community and not for the sake of village devices alone. The villageowned enterprise is expected to contribute significantly to the enhancement of PAD and realize the Pujon Kidul Village as an independent village. The Village Development Unit, through Sumber Sejahtera village-owned enterprise, is divided into several working groups, namely:

\section{Banking unit}

The existence of the village-owned enterprise is a means of economic equality. Among the work units provided by Sumber Sejahtera village-owned enterprise is the establishment of banking facilities. This banking cooperation with the government belongs to Bank Negara Indonesia (BNI). 
The existence of this unit provides banking facilities that are easily accessible by the people of Pujon Kidul Village. This service provides convenience to the community who want to make banking transactions such as opening savings, balance checks, money-making, interbank transfer, and saving as proclaimed by Bank Indonesia, a good practice program or banking services without offices. Customers will be given a smart BNI saving book and Automated Teller Machine (ATM) card. For cash deposits, they are also provided an Electronic Data Capture (EDC) machine or mini ATM as transaction media. This banking service helps people in the village of Pujon Kidul pay motor vehicle installments and electricity accounts and buy mobile phone credits and electricity tokens. This unit was also the facilitator of the Hopeful Family Program or Program Keluarga Harapan (PKH) in 2017, where the recipient community can do the pickup in the village. The contribution of the village banking unit in Pujon Kidul by the village-owned enterprise is quite significant and has become one of the contributors to $P A D$.

\section{Clean water unit}

Clean water is one of the basic human needs utilized sustainably for everyday needs such as drinking, bathing, and cooking. As one of the unlimited resources of natural resources, proper water consumption should be effortless to obtain; therefore, it is supposed that water is utilized and optimally controlled so that the potential in life is useful. As a water supply for the village, the village government formed the clean water unit, and this became part of the BUM unit of the Sejahtera village, which facilitates the availability of clean water for the village community. Consequently, there was an uneven water supply of unbalanced payments. After the construction of tendon water pipes by the village, which one of the village funds benefits, it provided much water capacity and the better installation of water pipes with measurable parameter water using. The water source is from Pitu and Tulung, where the water flows slowly all year long. From the water source, large pipes are installed that serves as the main pipeline and are planted in the soil to the residents' settlements. Next, from the main pipeline, a fork is made with a small pipe to the residents. Then a water meter is installed that serves to measure how much water is used by each home. This new system is advantageous, fair, and equitable, and the tariff of water charged to the community is quite cheap and affordable. Most of the village community of Pujon Kidul, especially the hamlet Krajan, already use this clean water facility and feel its benefits. Each month the officers of the meterization come to the people's houses to record the amount of water use and water payments are made at the village office every month. Establish cooperation between the community and the village government, a resident group of drinking water users was formed, and through this, people can give input related to the management and the problem of clean water. This clean water unit contributes to the village as a means of increasing the village's original income.

\section{Integrated waste management unit or Tempat Pengolahan Sampah Terpadu (TPST)}

Garbage is a very complex issue that occurs everywhere, including the village. Uncontrolled garbage impacts can lead to flooding and environmental pollution. With full awareness among the village community about the meaning of cleanliness, it is expected that the garbage problem will not be a big one with the increased production of garbage. As known, Pujon Kidul Village is increasingly popular with its Cafe Sawahs. With the number of visitors coming, this will cause an increase in the amount of garbage coming from food scraps, tissues, plastics, and food paper. Waste handling is part of the main program of the development of Pujon Kidul Village. The village head, Mr. Udi Hartoko, had the brilliant idea of carrying out an environment-based development that integrated waste processing. TPST is not only a place of disposal but also as a place of processing waste to make organic fertilizer. The garbage processing starts from households that are obliged to place trash out for collection. Moreover, all trash cans must have a lid. In 2016, 64 million IDR was allocated for the construction of integrated waste processing and 103 million IDR in 2017. The funds are used for the construction of integrated garbage disposal, the purchase of garbage crushing machines, and the manufacturing of garbage and operational carts. The task of TPST is to do the garbage sorting that comes from the residents' houses, which is in the garden after harvesting, and garbage from the Café Sawahs. Garbage sorting includes dry and wet waste and organic and non-organic. Used garbage, such as agricultural pesticides, undergoes special processing. Inorganic waste, such as plastic and paper, is collected 
for recycling, while organic waste processed into compost, which can be used by people to fertilize crops. The existence of TPST in Pujon Kidul Village affords benefits related to support the creation of a clean environment as well as reducing waste problems in the field of employment for the residents.

\section{Parking units and vouchers}

The existence of parking units and vouchers can be said to be one of the biggest donors of PAD in the Pujon Kidul Village. Because this unit is directly related to the Café Sawah unit, it has a significant income acquisition based on the number of tourists or visitors who come to Café Sawah. The Café has become a significant tourist attraction and includes a parking payment system and also an entrance fee. Parking payment is coupled with a nominal voucher that can be used by visitors in the Café field area. Any visitors or tourists who come to the Café Sawah will be charged an admission fee of 8.000 IDR. Each entry ticket includes a voucher with a value of 5.000 IDR and can be used as a means to buy food and drinks. If the purchase exceeds the value of the visitor voucher, this is a drawback. Each vehicle is charged a different parking fee according to the type. The income from village parking payments is used for the development of Pujon Kidul Tourism Village. According to a worker in the ticket section, the voucher can be applied inside or outside the parking area so that long queues and clutter parking of vehicles do not happen. The overall parking attendant is equipped with procedures for arranging the correct vehicle parking. The most critical issue of this unit is the limited area of parking. The parking lot is still using village land, and planning to expand the parking lot that is being discussed, considering the ever-increasing tourists or visitors, especially when entering the holiday season.

\section{Agricultural unit}

Most of the villagers of Pujon Kidul are well-known for their cultivation as both rice farmers and agricultural farmers. The village-owned enterprises have formed an agricultural unit to create a breakthrough resulting in a reliable farmer who produces agricultural production and quality plantations. This farm unit has an area of about 6.000 square meters. Mostly planted are horticultural crops such as cabbage, mustard greens, tomatoes, chili peppers, and carrotsn. Several people do the processing of land according to their duties and responsibilities. This unit's main task is to produce and develop agricultural products and plantations in the Pujon Kidul Village. In addition, this unit serves in the field of handling the agricultural sector. This agricultural unit also cooperates with some farmers to find solutions to any problems that arise. In addition to producing agricultural and plantation production, this unit also produces liquid fertilizer and manure. The fertilizer has already been trialed on their field and other farmers' land and shows excellent and satisfactory results. Training and counseling from related agencies are often held to improve the quality of agricultural products and fixed resources. All agricultural and plantation products are sold to the third-party big sellers' distribution and become a source of village income. Some of them are also sold in the café area where the visitors target the Café Sawah.

\section{Paving unit}

Paving units are made for the empowerment of the village community in Pujon Kidul, where the entire process involves village communities. Paving units are units that work on the manufacture of paving, brick, and culverts. Production involves working on projects such as field paving, cafe parking, rice paddy fields, village roads, drainage, and the homes of residents. The unit employs four people to work in this unit. They were functioned to make the shape of paving, producing processes, and organized it become a buyable commodity. The advantage of the existence of the paving unit is that it can reduce the cost of village shopping, especially for plants that require necessary materials in the form of paving. The raw materials can be acquired from the building materials store in Pujon Kidul village, such as sand, stone ash, and cement. It also gives benefits to all parties in that prices are cheaper than if bought outside Pujon Kidul village. In the process of making brick, using a standard size machine pole, it can produce 1.000 brick or paving each day. Before being marketed, paving or bricks must be put through test trials first to maintain the quality of the product. 


\section{Live-in unit}

A tourism program village-owned enterprise is included in one of the units of the village-owned enterprise of the south of the Kidul. The live-in program is offered to individual families, schools, institutions, companies, or groups that want to enjoy a long holiday in Pujon Kidul village. Tourists or visitors who participate in this program enjoy a variety of activities, such as planting rice, vegetable picking, milking cows, or making various food processed crafts. Cooking and eating together with the citizens, is also a routine activity done while attending this program. A caring and respectful attitude to fellow environmentalists and honest attitudes of life are expected to be internalized to tourists in this live-in tourism activity. The live-in program is a learning program to understand the environment of the villagers and their activities. This program has shown an increase in interest for tourists, thus contributing to the increase in $P A D$.

\section{Café Sawah}

Café Sawah is a famous icon in social and tourist activists. The café is a popular destination during an increasingly vibrant tourist business competition and has become a tourist attraction rich with rustic nuance. Mbaiwa (2011) and Zhang (2012) stated that tourism village development could provide many benefits, including 1) enhancing the rural collective economy, 2) beautifying the rustic appearance, 3) strengthening the rural civilization construction, 4) increasing the community incomes, 5) changing community traditional livelihood activities and lifestyles, and 6) reducing the urban-rural gap and building a harmonious society. Indeed, the establishment of village tourism should offer the community an opportunity to improve their houses and neighborhoods. For this reason, the activities of a tourism village need the participation of the local community. First, before becoming a cafe, this land was a sawah or crooked land for the selected head of the village with a beautiful view of the mountains. Through village and community devices, it has become a rural tourist destination that can accelerate the development of the village economy. The Café Sawah was first launched in 2016 and stood on a land area of $6.397 \mathrm{~m} 2$, offering the concept of a nostalgic holiday. This destination is designed to enjoy the natural beauty of the mountains and Sawahs while enjoying the typical culinary delights of the countryside. Visitors can enjoy a variety of culinary offerings while seeing farmers cultivate Sawahs and gardens. Along the way to entering the Cafe Sawah area, visitors will be presented with the beauty of green plants planted by farmers in Pujon Kidul Village.

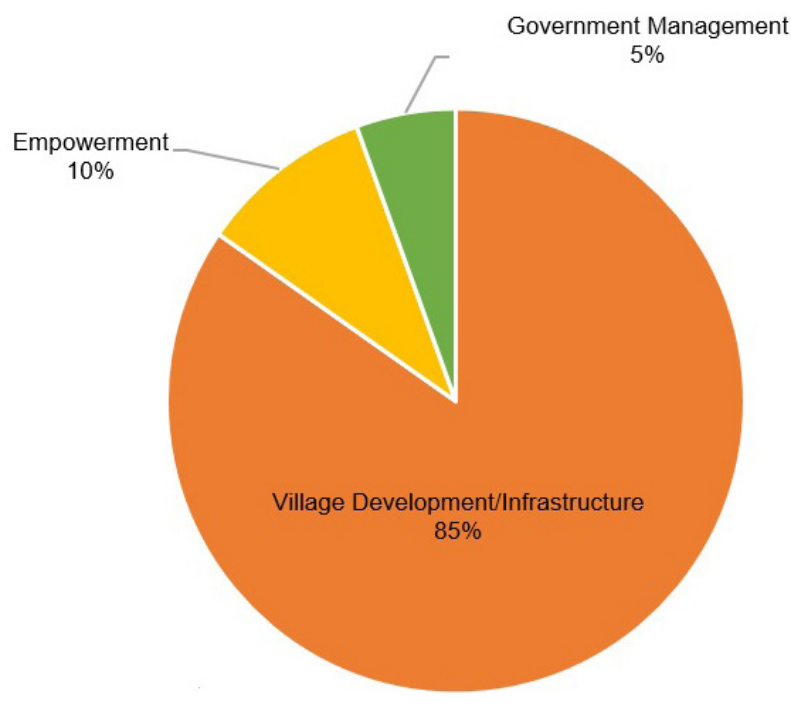

Figure 2.

Budget-realization of village funds in Pujon Kidul year 2018

The plants include a variety of vegetables, such as cauliflower, watercress, mustard, celery, and scallion. The most exciting thing about Café Sawah is that there are many photo opportunities with incredible backgrounds and beautiful natural landscapes that are popular through social media. The 
Café Sawah area also has a heart-shaped garden with fountains and the background of the dragonfly statue in the tourist village of Pujon Kidul. It is the most exciting photo spot that attracts visitors to capture their holiday moments with friends and family. The rides around the Café Sawah terraces are offered to visitors, especially children, and there is a cultural park with traditional arts such as dance, sculpture, and various other traditional Javanese culture souvenirs. There is also a pendopo that is commonly used for meetings and study of appeals. This pendopo can also be rented for such as meetings, recreation community, and other events. The area also has Wahana Fantasy Land and many interesting photo spots to capture holiday moments in Café Sawah in Pujon Kidul Village. In addition, tourists or visitors can enjoy strawberry picking according to their taste with the cost calculated based on the number of strawberries picked.

The field terraces serve a menu of village cuisine, such as urap-urap (salad dish), corn rice, friend rice, vegetables from the farmers' gardens that are processed with a spicy taste, and tempeh mendol. The dining experience in the café area has affordable prices ranging from 10.000 IDR to 50.000 IDR per serving, and a buffet is also offered. Visitors can also enjoy traditional snacks that are sold in the culinary booths along the way to the café. Souvenirs, fruits, and vegetables are the result of empowering villagers and along the road to the Café Sawah, on the right and the left, is a stand of fresh fruits, such as apples and durians strawberry, oranges, guava, and avocado. There is also a study stand of vegetables such as cabbage, cauliflower, carrot, and mustard. Pujon Kidul Village was created as an Regional Revenue and Expenditures Budget or Anggaran Pendapatan dan Belanja Daerah $(A P B D)$ as a guide form of using village funds. They analyzed what the society needed using a bottom-up policy. From the findings, they decided on a top-down policy of using village funds (Figure 2). Table 2 explained that the research can be concluded by using the matrix of policy evaluation. Using Dunn's theory, the output of the policy, described the performance and using the priority of village fund. What happened in Pujon Kidul was the realization of village funds, which we concluded at the end (Table 2). Based on Table 2, row is priority using and column is evaluation perspective.

Table 2.

Matrix of policy evaluation using Dunn's theory

\begin{tabular}{|c|c|c|c|c|c|}
\hline $\begin{array}{l}\text { Priority using } \\
\text { Evaluation } \\
\text { perspective }\end{array}$ & Development & Empowerment & $\begin{array}{l}\text { Government } \\
\text { management }\end{array}$ & $\begin{array}{l}\text { Otherl } \\
\text { unpredictable } \\
\text { needs }\end{array}$ & Total \\
\hline Effectiveness & 5 & 5 & 4 & 4 & 18 \\
\hline Efficiency & 5 & 4 & 4 & 3 & 16 \\
\hline Adequacy & 5 & 3 & 3 & 3 & 14 \\
\hline Equity & 4 & 3 & 3 & 2 & 12 \\
\hline Responsiveness & 5 & 3 & 3 & 2 & 13 \\
\hline Accuracy & 4 & 3 & 2 & 3 & 12 \\
\hline Total & 28 & 21 & 19 & 17 & \\
\hline
\end{tabular}

Note: 1:Very lacking 2: Less 3: Enough 4: Good 5: Very good

Source: Researcher adoption policy evaluation perspectives from Dunn (2003) compared with R।

\section{Conclusion}

research findings

Policy evaluation to develop an Agro-Tourism Village with a village fund is ongoing as well as the law of using priority from the Ministry of Villages and PDTT. The policy evaluation Wahab (2011), as the practice that has social-politics complexity, contextually relates to technical appraisal, outputs, and what has been achieved. The indicators of the sound output indicate that some areas have the best results. From the perspective of effectiveness, efficiency, adequacy, and responsiveness of development, it was in the first place; then, the second place was from empowerment in effectiveness and efficiency perspective. And the third in government management from the perspective of effectiveness and efficiency. Evaluation of a policy (Taylor 2006) Presented as discursively 
constructed within political, scientific, and popular discourse. We can summarize that the accuracy, alignment, and responsiveness in empowerment should be increased because, from the concept of development, the first key is to develop human resources, mindset, and habituation urgently. Then we can achieve sustainable locality-based development. The government has been doing well, but from some perspectives, it could be further maximized.

\section{References}

Anderson JE (1979) Public Policy Making (2nd Edition). New York: Holt, Rinehart and Winston.

Anto RP \& Amir M (2017) Competence of village apparatus in management of village funds in North Konawe Regency-Indonesia. IOSR Journal of Business and Management (IOSR-JBM) 19 (11):66-71.

Balan M \& Burghelea C (2015) Rural tourism and its implication in the development of the Fundata Village. Procedia - Social and Behavioral Sciences 188 (2015):276-281. [Accessed 22 June 2019]. https://doi.org/10.1016/j.sbspro.2015.03.393.

Dunn WN (2000) Pengantar Analisis Kebijakan Publik. Yogyakarta: UGM Press.

Dunn WN (2003) Analisis Kebijakan Publik. Yogyakarta: UGM Press.

Dye TR (2013) Understanding Public Policy (14th Edition). Florida: State University.

Hamzah AS \& Irfan M (2018) Law enforcement of constitutional court decision No.69/PUUXII/2015 (Mixed marriage issue without marriage agreement). Jurnal Notariil 3 (1):1-12. https://doi.org/10.22225/jn.3.1.597.1-12.

Hartoyo, Haryanto S, \& Fahmi T (2018) Towards a new village development paradigm in Lampung Province, Indonesia. Journal of Legal, Ethical and Regulatory 21 (Special Issue 2018):1-18.

Howlett M (2007) Policy Analytical Capacity As a Source of Policy Failure. In: Workshop on Policy Failure Annual Meeting of the Canadian Political Science Association University of Saskatchewan, 1 June 2007, Canada.

Howlett M (2011) Designing Public Policies: Principles and Instruments. New York: Routledge.

Howlett M (2019) The Policy Design Primer. New York: Routledge.

Mbaiwa JE (2011) Changes on traditional livelihood activities and lifestyles caused by tourism development in the Okavango Delta, Botswana. Tourism Management 32 (5):1050-1060. https://doi.org/10.1016/j.tourman.2010.09.002.

Phillips R \& Pittman RH (2014) An Introduction to Community Development. New York: Routledge.

Setiawan B, Rijanta R, \& Baiquni M (2017) Sustainable tourism development: The adaptation and resilience of the rural communities in (the tourist villages of) Karimunjawa, Central Java. Forum Geografi Indonesian Journal and Spatial and Regional Analysis 31 (2):232-245. https://doi.org/10.23917/forgeo.v31i2.5336.

Suryani A \& Irfan M (2016) Local wisdom based tourist village organization in Lombok tourist area. E-Journal of Cultural Studies 9 (4):1-10.

Taylor D (2006) Critical policy evaluation and the question of values: A psychosocial approach. Critical Social Policy 26 (1):243-267. https://doi.org/10.1177/0261018306059774.

Vitasurya VR \& Pudianti A (2016). Sustainable waste management of traditional craft industry in Lopati Tourism Village, Yogyakarta. DIMENSI: Journal of Architecture and Built Environment 43(2):123-130. https://doi.org/10.9744/dimensi.43.2.123-130.

Wahab SA (2011). Pengantar Analisis Kebijakan Publik. Malang: UMM Press.

Zhang L (2012) Smart tourism: The coming age of customization and intelligent public services. Journal Tourism Tribune 27 (5):66-73. 